\title{
Rare case reports of ruptured ectopic pregnancy
}

\section{Dhruba Prasad Paul, Dibakar Debbarma*, Ashis Kumar Rakshit}

Department of Obstetrics and Gynecology, Agartala Government Medical College and GBP Hospital, Agartala, Tripura, India

Received: 11 October 2018

Accepted: 27 October 2018

\section{*Correspondence:}

Dr. Dibakar Debbarma,

E-mail: dibainsominiac@gmail.com

Copyright: ( $)$ the author(s), publisher and licensee Medip Academy. This is an open-access article distributed under the terms of the Creative Commons Attribution Non-Commercial License, which permits unrestricted non-commercial use, distribution, and reproduction in any medium, provided the original work is properly cited.

\begin{abstract}
Two patients of 30-35 years of age presented in Gynecological emergency of Agartala Government Medical College at unstable condition with the diagnosis of ruptured ectopic pregnancy. Both the cases were taken for emergency laparotomy after initial resuscitation, investigations \& arrangement of blood products. In both the cases rupture were found in right side and hence right sided salpingectomy done in both the cases. Both the tubes (affected) after laparotomy were sent for histopathological examination where both the reports came to be partial mole. Ectopic hydatiform mole (either complete or partial) are rare events, among these Ectopic partial moles are rarer. Both the cases were in regular follow up \& B-HCG levels came to the base level within 6-7 wks. The 1st case became pregnant after 9 months of laparotomy.
\end{abstract}

Keywords: Ectopic, Hydatidiform moles, Laparotomy

\section{INTRODUCTION}

Hydatidiform moles are abnormal gestation characterized by the presence of hydropic changes affecting some or all of the placental villi. Hydatidiform moles arise as a result of fertilization of an abnormal ovum of which the majority originate within the uterine cavity. The occurrence of a hydatidiform mole within ectopic gestational tissue is rare. ${ }^{1}$ There are two types of Hydatidiform mole: complete or partial, and these differentiate based on clinical presentation, chromosomal pattern, histology, and outcome.,3 Partial Hydatidiform mole, as with our cases, occur when the ovum is fertilized by either two sperm or one diploid sperm causing a triploid mole (69XXX, 69XXY, or 69XYY). ${ }^{3,4}$

Partial Hydatidiform moles may be associated with a fetus, even allowing for a detection of fetal cardiac activity in some cases. ${ }^{5}$ Thus, along with its rarity, can make ectopic $\mathrm{H}$. Mole a difficult diagnosis, consequently causing it to be overlooked for simple ectopic. While ectopic pregnancy and molar pregnancy are not rare events (approximately twenty in every 1000, and one in every 500 to 1000 pregnancies respectively), the combination of the two, an ectopic H. Mole, is an extremely rare event. ${ }^{6-8}$ There have only been a small number of molar ectopic pregnancies reported in the literature with estimates of incidence.

\section{CASE REPORT}

\section{Case 1}

The patient is a 35 years old GTPAL 3, 1, 0, 1, 1 who presented to the gynecological emergency of Agartala Government Medical College and GBP Hospital on 01/01/2018 with pain lower abdomen with short periods of amenorrhoea. On examination patient is vitally unstable, severely pallor, tachycardia present. Per abdomen examination mildly distended, guarding and rigidity present, more on right side. Per vaginal examination shows cervical motion tenderness with right adenexal mass with diffuse tenderness.

Urine pregnancy was positive. USG shows empty uterine cavity with free fluid in POD. Emergency laparotomy 
was done in view of acute ruptured ectopic pregnancy. Intra-op findings reveal right sided ampullary ruptured ectopic pregnancy.

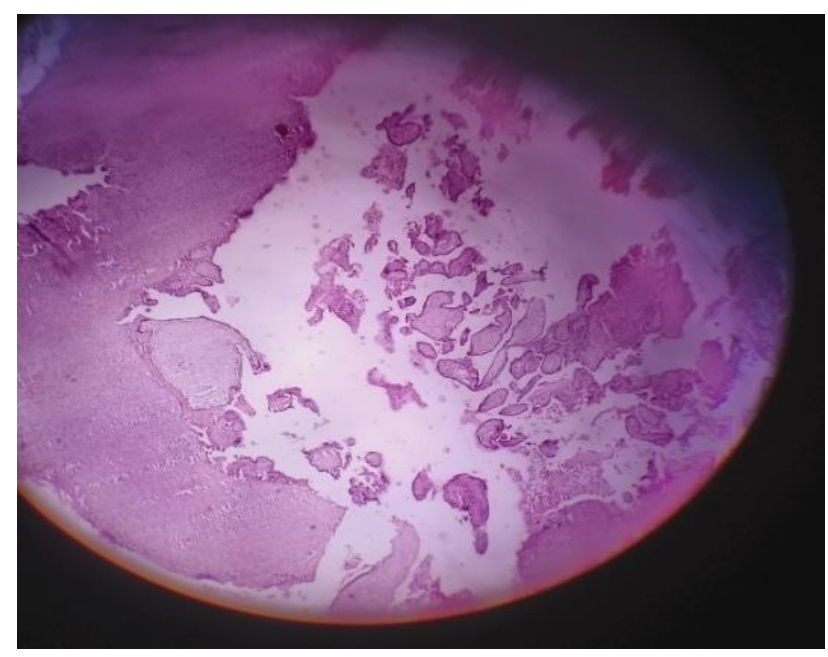

Figure 1: Partial hydatidiform mole of ectopic pregnancy.

Right sided salpingectomy done, and tissue was sent for histopathological examination (HPE). Histopathological report shows- irregular scalloped vesicular villi admixed with normal appearing villi. Cistern formation, nucleated RBC and fetal parts noted- features are suggestive of partial mole (Figure 1). The postoperative evaluation was favorable.

The patient was monitored by $\beta$-HCG level, which normalizes after 7 weeks $(2.4 \mathrm{mIU} / \mathrm{ml})$ from the date of operation. But she didn't have any period after laparotomy till 20/08/18. She was investigated for secondary amenorrhoea and necessary treatment was given. After that she was advised to do USG-pelvis which she did on 06/10/18 and that came to be of intra uterine pregnancy of $7+4$ weeks.

\section{Case 2}

The patient is 30 years old GTPAL 3, 2, 0, 0, 2 who presented to the gynecological emergency of Agartala Govt. Medical College and GBP Hospital on 25/1/2018 severe pain lower abdomen with spotting PV with hypovolemic shock with 2 months amenorrhea. Urgent UPT was done which came positive.

On examination patient is looking very pale, lethargic, disoriented, tachycardia present, blood pressure 80/50 $\mathrm{mmHg}$, abdomen is distended, guarding and rigidity present on palpation. Paracentasis done -came positive for haemoperitonium, $\mathrm{p} / \mathrm{v}$ examination reveals-fullness of POD, cervical motion tenderness was present.

Emergency laparotomy was done in view of suspected ruptured ectopic pregnancy intra-op finding shows right sided ampullary ruptured ectopic pregnancy with huge haemoperitonium approximate 2 litres. Right sided salipingectomy with left sided tubarligation were done and specimen sent for HPE. Histopathological report shows-occasional chorionic villi with hydropic change and focal proliferation of trophoblastic cells suggestive of partial mole (Figure 2). Post-operative $\beta$-HCG level normalize within 6 weeks $(2 \mathrm{mIU} / \mathrm{ml})$ after laparotomy. She resumed her period after 2 months.

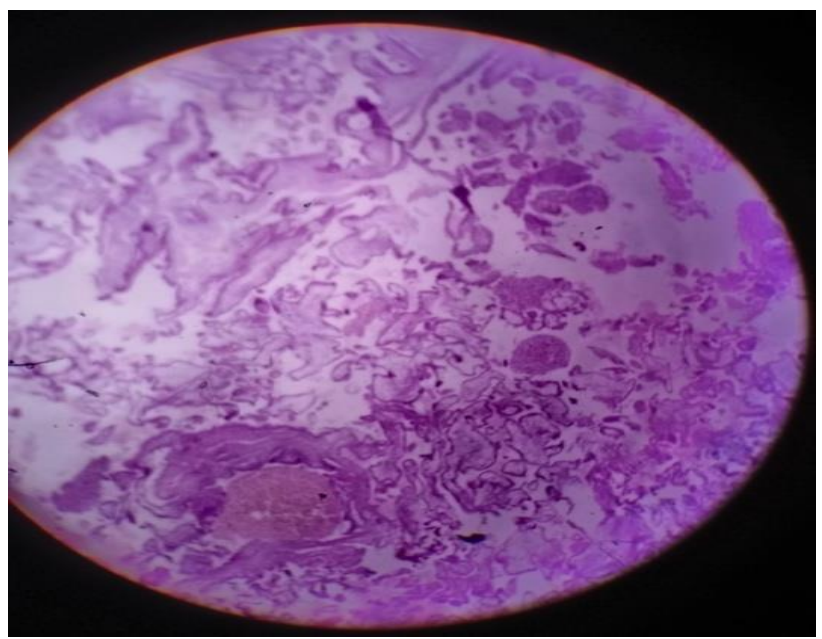

Figure 2: Partial hydatidiform mole of ectopic pregnancy.

\section{DISCUSSION}

Molar ectopic pregnancy becomes even more difficult to diagnose when it occurs in heterotopic pregnancies, where the patient may present with shock, weeks after evacuation of the intrauterine pregnancy. ${ }^{9}$ The condition might then be confused with degenerated fibroid seen during pregnancy.

Although extremely rare, an extrauterine molar pregnancy should form part of the differential diagnoses in cases of intra-uterine pregnancy complicated by the presence of a pelvic mass, vascularity and high levels of serum $\beta$-hCG. ${ }^{10}$

Monitoring $\beta$-hCG titers following conservative management of suspected ectopic pregnancies is important, not only to diagnose persistent ectopic gestation, but also to rule out the presence of malignant trophoblastic diseases. ${ }^{11}$ The current trend in the treatment of ectopic pregnancies is through conservative surgery and monitoring of $\beta$-hCG titers to avoid missing a choriocarcinoma developing in an ectopic gestation, even though this is a very rare condition. ${ }^{12}$

Mediastinal metastasis of choriocarcinomas following ectopic pregnancies cause dyspnoea, pleural effusion and thoracic pain. ${ }^{13}$ One extensive study on routine preevacuation ultrasound diagnosis of hydatidiform mole suggests that ultrasonography identifies less than $50 \%$ of hydatidiform moles. Detection rates are however higher 
for complete moles, compared to partial moles and improve even further after the $14^{\text {th }}$ week of gestation. ${ }^{14}$ Histopathological examination of products of conception remains the current gold standard for the diagnosis of gestational trophoblastic neoplasia. There is also a possibility of over-diagnosis by histological examination, especially in early ectopic tubal pregnancies, due to a more florid extra-villous trophoblastic proliferation compared with evacuated uterine products of conception. ${ }^{1}$ Extra caution should be taken to strictly apply the morphological criteria of circumferential trophoblastic proliferation, hydropic changes, scalloped villi and stromal karyorrhexis for diagnosis. ${ }^{15}$

\section{CONCLUSION}

Ectopic molar pregnancy is a rare condition, which can occur at any place in the pelvic cavity. Invasive mole and choriocarcinoma might even follow such a pregnancy. However, ultrasonography might not be able to fully diagnose ectopic molar pregnancies, leaving histopathological examination of the conception products the current gold standard for the diagnosis.

\section{ACKNOWLEDGMENTS}

Authors would like to thank Prof. Mamata Pradhan, Head and Dr. Ashis Kumar Rakshit, Assistant professor, Dept. of Obstetrics and Gynecology for their effective encouragements.

Funding: No funding sources Conflict of interest: None declared

Ethical approval: The study was approved by the Institutional Ethics Committee

\section{REFERENCES}

1. Burton JL, Lidbury EA, Gillespie AM, Tidy JA, Smith O, Lawry J. Overdiagnosis of hydatidiform mole in early tubal ectopic pregnancy. Histopathol 2001;38(5):409-17.

2. Szulman AE, Surti U. The clinicopathologic profile of the partial hydatidiform mole. Obstet Gynecol. 1982;59(5):597-602.

3. Szulman AE, Surti U. The syndromes of hydatidiform mole. I. Cytogenetic and morphologic correlations. Am J Obstet Gynecol.1978;131(6):66571.

4. Vassilakos P, Riotton G, Kajii T. Hydatidiform mole: Two entities: A morphologic and cytogenetic study with some clinical considerations. Am J Obstet Gynecol. 1977;127(2):167-70.

5. Berkowitz RS, Goldstein DP, Bernstein MR. Natural history of partial molar pregnancy. Obstetrics and gynecology. 1985;66(5):677-81.

6. Hwang JH, Lee JK, Lee NW, Lee KW. Molar ectopic pregnancy in the uterine cornus. J Minimal Invas Gynecol. 2010;17(2):239-41.

7. Gillespie AM, Lidbury EA, Tidy JA, Hancock BW. The clinical presentation, treatment, and outcome of patients diagnosed with possible ectopic molar gestation. Int J Gynecolog Cancer. 2004;14(2):366-9.

8. Altieri A, Franceschi S, Ferlay J, Smith J, La Vecchia C. Epidemiology and aetiology of gestational trophoblastic diseases. The lancet oncology. 2003;4(11):670-8.

9. Leung F, Terzibachian JJ, Chung Fat B, Lassabe C, Knoepffler F, Maillet R, et al. [Heterotopic ovarian hydatidiform mole. A case report]. Gynecol Obstet Fertil. 2009;37(9):749-51.

10. Snyman LC. Case report of an intra-uterine pregnancy complicated by an ectopic invasive molar pregnancy. Southern Afr J Gynae Oncol. 2009;1 (2):69-70.

11. Rotas M, Khulpateea N, Binder D. Gestational choriocarcinoma arising from a cornual ectopic pregnancy: a case report and review of the literature. Arch Gynecol Obstet. 2007;276(6):645-7.

12. Bakri YN, Amri A, Mulla J. Gestational choriocarcinoma in a tubal ectopic pregnancy. Acta Obstet Gynecol Scand. 1992;71(1):67-8.

13. Kagel T, Lemburg SP, Müller KM, Laczkovics A, Nicolas V, Heyer CM. [Mediastinal metastasis of a tubal choriocarcinoma following ectopic pregnancy as a rare cause of thoracic pain]. Zentralbl Gynakol. 2006;128(2):90-4.

14. Fowler DJ, Lindsay I, Seckl MJ, Sebire NJ. Routine pre-evacuation ultrasound diagnosis of hydatidiform mole: experience of more than 1000 cases from a regional referral center. Ultrasound Obstet Gynecol. 2006;27(1):56-60.

15. Burton JL, Lidbury EA, Gillespie AM, Tidy JA, Smith O, Lawry J, et al. Over-diagnosis of hydatidiform mole in early tubal ectopic pregnancy. Histopathology. 2001;38(5):409-17.

Cite this article as: Paul DP, Debbarma D, Rakshit AK. Rare case reports of ruptured ectopic pregnancy. Int J Reprod Contracept Obstet Gynecol 2018;7:5201-3. 